\title{
Investigating Factors Affecting the Implementation of Communicative Language Teaching in East Gojjam Zone Agricultural Technical and Vocational Educational Training Colleges ESP Class Rooms
}

\author{
By Meseret Abebe (MA in TEFL) \\ Mekdela Amba University, College of Social Scincies and Humanities, \\ Departement of English Language and Literature
}

\begin{abstract}
This study was designed to investigate the major factors affecting the implementation of communicative language teaching in East Gojjam Zone ATVET Colleges in ESP class room setting. Qualitative research design was used for this research. Participants of the study were work place communication Teachers of TEVT teachers and college academic vice deans from Mertule Mariam, Motta, Bichena and Debre Work ATVET colleges. The main data gathering tools were questionnaire, interview, and document analysis. The collected data were categorized and discussed using figures with a qualitative description below. The result of the study revealed that ESP course teachers in TVET confront with several factors in implementing communicative language teaching. It was emphasized that the absence of language teachers from TVET system, unable to prepare a CBLM nationally, shortage of giving on job language teaching training, TVET current language teaching policy from MOE related factors; lack of time ,heavy work load, lack of supervision from institutional related factors; deficiency in spoken English, lack of training in CLT, misconception about CLT, lack of experience in CBLM development from teachers related factors and low English proficiency, passive style of learning and resistance to participate in communicative activities were the major factors that challenge teachers in implementing CLT approach in ESP class room. Moreover, the study discovered that the work place communication CBLM activities were not prepared based on the common features of communicative activities. Thus, it is recommended that any concerned bodies like deans, teachers, students, MOE, industrial sectors that need TVET graduates, especially federal TVET Bureaue heads should cooperate each other and give immediate solution in the way that the implementation of communicative language teaching can improve in East Gojjam Zone agricultural, technical and vocational colleges.
\end{abstract}

Keywords: CLT, ESP, and implementations

DOI: $10.7176 /$ JLLL/67-01

Publication date: April $30^{\text {th }} 2020$

\section{I.INTRODUCTION}

\subsection{BACK GROUND OF THE STUDY}

English is the international languages of education, science, business, politics and culture. Due to this, people throughout the world need to learn this international language for a better communication in this global world. Accordingly, policy makers all round the world gives apriority for the teaching learning of English and stated clearly in their educational policy in their countries. The same thing is true in Ethiopia. In its educational and training policy, Ethiopia clearly recognize English to be used as a medium of instruction in secondary and higher institutions including TVET and to be taught as a subject starting from grade one - grade twelve (Education and training policy MOE 1994). This implies that the English language teaching in the country is a decisive issue.

In order to meet these demands it is worth giving due attention to enhance the quality of English language education in Ethiopia. As a result, the country started teaching of English as a subject from grade one up to twelve and began to use the language as a medium of instruction for secondary and tertiary educational institutions. Not only that the country also encourage EFL teachers to apply modern language teaching approaches like CLT in their teaching and attempted to design communicative based curriculum and syllabus, began to prepare teaching and learning materials communicatively. However, the country tried a lot to make the language teaching communicative based the implementation of CLT has been affected by various problems. The implementation of CLT in ESP class room in TVET is still remains a problem, yet, to be solved. So, for the practicality of communicative language teaching in ESP class rooms, different factors affecting teacher's implementation of the CLT need to be considered.

Different scholars have said a lot about communicative language teaching and the problems seen in its implementation particularly in educational contexts where English is taught as a foreign language. For instance Richards (2006) reveals that CLT method placed an essential emphasis on communication in the language classrooms. It gives priorities for the need and interest of individual learners and the aim of teaching is to facilitate learning not to control the learning process (Richards 2006). According to Savigon (1991:261), CLT is 
seen to be an international effort to respond the present day language learners in many different contexts of learning. Another scholar William Little Wood (1981) described that the CLT plays a balanced attention to functional as well as structural aspects. Regarding with this Larson freeman (2000) also stated that CLT advocated teaching practices that develop communicative competence in an authentic context. Wright (2000) stated that there exist a number of problems in teaching English as a foreign language and applying the principles of CLT in the actual classroom situation in schools. In this regard he dictates that physical constraints ,preference of grammar, exam practices, students reluctant to use English to do activities in group, lack of supplementary materials and lack of confidence in using English are some of the problems that act against the implementation of CLT.

There are also local studies conducted on CLT and its applications in Ethiopian context. For instance a study done by Alemayehu Hailemariam (2012) realized that large class size and unsuitability of the class room to act out communicative activities are the major factors. In addition a study done by Surafel (2002) shows that in adequate back ground knowledge of the students, scarcity of text books, exam practices and absence of supplementary materials for listening and reading activities are the major factors that affect the implementation of CLT in EFL class room. Moreover, a study in Arba Minch University entitled in "assessing the implementation of CLT for language teachers in Ethiopian universities by A.GANTO,F.COENDERS AND J.VOOGT realized that teachers pedagogical knowledge, teachers insufficient subject matter knowledge, lack of support material(teachers guide) students shortage of experience with the approach, large class size, teachers lack of interest to properly implement the approach are the major factors that affect the implementation of CLT.

Not only in high school and universities, different researches were conducted in TVET regarding English language teaching. But, they were conducted before TVET made a reform in their educational curriculum when a general English text book for grade 11 and $12^{\text {th }}$ were given to TVET students. Therefore, most of the past researchers focus area was in relation with identifying the language need of the TVET students to prepare an ESP course for the trainees. For example, Tagel Elias, in 2007 conducted a research on an investigation in to English language course need of electricity students of Dilla TVET college; discovering the English language needs of learners the case of Ethiopian Police college by Mohammed Sied in 2007 , English language need analysis of 10+ 3 Thank Mechanics trainees for Major General Mulugeta Buli TVET college by Gashaw Shewangizaw in 2007 were conducted from the assumption the course book which was used to teach TVET students was not prepared based on the learners language need as they are a trainees for the better work of tomorrow.

Most of the studies mentioned above were conducted in high school and higher institutions. They were also conducted in a general English class room context. TVET's past researches were also conducted in relation with identifying the language needs of TVET students to prepare an ESP course for the trainees. Therefore, this study is confined to investigate specifically factors that affect teacher's implementation of CLT at TVET colleges in ESP classroom settings that aims to bridge a gap. Since the former studies were delimited to high school, higher institutions and in a general English classroom, one cannot find enough data on factors affecting the implementation of CLT in TVET ESP class rooms, because the environment, the nature of students and teachers and their linguistic competency, the nature of language teaching may differ from that of universities and high schools.

\subsection{Statement of the Problem}

Now a day`s, communicative language teaching is becoming the most widely used approach in EFL context and has got a great emphasis throughout English language teaching. Teachers of English in many countries have been encouraged to adopt CLT approach (Anderson1993; Savignon 2002). Teachers of English in Ethiopia are also encouraged to adopt CLT approach and the countries current language policy encourages the application of CLT approach with the learners at the center of the instructional process (ICDR1994). Currently ELT materials are also being designed and published based on the principles of communicative language teaching in contrary to the traditional teaching approach. The materials are prepared based on the functional aspects of the language in which the tasks are more of communicative and enable students to use English for international communication where necessary. This is applied mostly for high school and preparatory school students.

In the contrary, the practice of English language teaching in TVET colleges is somewhat far from the countries objectives of language teaching. Despite its shift from the general English towards ESP, TVET do nothing comfortable for English language teaching. Its major focus is only on vocational and agricultural areas. First of all TVET ignore English language teachers from its educational system without any logical finding in the area of language teaching and make the course to be offered by non English language professionals. TVET thought that English language teaching as such a simple task that one can easily teach without any language training.

In addition, in TVET this time there is no as such centrally developed CBLM for language courses. It is left for the non professional teachers in language to deliver the material for the language course which is strange for 
them. Moreover, there is no any COC assessment which measures students as well as teachers language proficiency at the end of the training level. The assessment is only for their major areas of specialization.

Not only TVET, MOE also has its own share for the improper practice of communicative language teaching in TVET. It is unknown whatever the case is it has said nothing opposite when the course is offered by non professionals. It cannot prepare centrally developed CBLM for the ESP course as like as high schools because there are a number of TVET colleges in the rural area where there is no internet access.

Due to the above mentioned problems of TVET and MOE, ESP teachers in ATVET colleges are observed when they are unable to use communicative activities, do not make their lesson interactive and practical using CLT principles, lacks interest to offer the course without being professional in the area.

Generally, the implementation of CLT in ESP class room in ATVET Colleges is still remains a problem, yet, to be solved. Various factors affect the implementation of CLT in TVET ESP classrooms. As a result of the implementation of CLT can be determined by various factors, this study is tried to investigate factors that affect the implementation of CLT in East Gojjam Zone ATVET colleges.

Not only that but also, TVET is hardly addressed in research in Ethiopia to solve the problems that are related with language learning. A descriptive survey conducted in two prominent universities, Addis Ababa and Jimma reputable journals reveals this fact. Out of 68 publications from 2002 to 2011 in the Ethiopian Journal of Education of AAU, only one title is about TVET. Out of 100 publications from 2005 to 2011 in Ethiopian Journal of Education and Science of Jimma University none is about TVET (partnership meeting Nov, 2013 Jimma University.)

These, the research gap in TVET related with language teaching and the poor implementation of communicative language teaching in TVET ESP class room motivated the researcher to investigate the factors that affect the implementation of communicative language teaching in the ESP class rooms in East Gojjam Zone ATVET Colleges.

As far as the researchers' knowledge is concerned, no study was conducted in TVET in relation with investigating factors that affect the implementation of CLT in ESP class rooms. Due to the fact that the factors that affect the implementation of CLT may vary from one educational institution to the other institution, the researcher is motivated to investigate factors that affect the implementation of CLT in ESP class rooms of East Gojjam ATVET Colleges.

\subsection{Objectives of the Study}

1.3.1. General Objective

The main objective of the study was to investigate factors that affect the implementation of CLT in ESP class room in East Gojjam ATVET Colleges.

1.3.2 Specific Objectives of the Study

The specific objectives of the study are, therefore, to

1. Examine the ESP teachers towards CLT.

2. Assess to what extent the course CBLM s are prepared based on the principles of communicative language teaching.

3. Explore the basic factors that hinder the implementation of CLT in ESP class room.

\subsection{Research questions}

In order to investigate the factors that affect the implementation of CLT, the researcher suggested the following questions to be answered in the study.

1. What perception do the "work place communication course" teacher hold about CLT?

2. To what extent do the activities in the course CBLMs are prepared communicatively?

3. How do the TVET students 'influences the implementation of CLT in ESP classes of TVET Colleges?

4. how do the college management/adiministrators see the implementation of CLT in ESP classes of TVET Colleges?

5. How teachers` influence the implementation of CLT in ESP classes of TVET Colleges?

6. How and to what extent the MOE influence the implementation of CLT in ESP classes of TVET Colleges?

7. How conducive and adequate in materials are the TVET colleges to implement CLT in thier language teaching.

\section{RESEARCH DESIGN AND METHODOLOGY}

In this chapter, the research design, the source of data, data gathering tools, methods of data analysis, data presentation procedures are presented. 


\section{Research Design}

The main objectives of the study was to investigate the factors that affect the implementation of CLT at TVET College ESP classrooms. For the successful completion of the study, the descriptive survey study design was used. According to Cohenmanian and Marrison (2005),descriptive research design helps researchers to identify conditions or relationships that exist; practices that prevail; believes, point of views, attitudes that are held ;processes that are going on, effects that are being felt; or tends that are developing.

A qualitative approach was employed. This indicates that the analysis of the data is going to be presented in words in relation with factors that affect the implementation of CLT in the ESP class room.

Participants of the study were from Amhara regional State East Gojjam Zone ATVET colleges; namely: Mertule Mariam ATVET College, Motta TVET College, Bichena TVET College and Debere Work ATVET College. They were "Work Place Communication" teachers and college deans. This is because the researcher believed that teachers are the reactionaries in the language teaching learning process. Due to this, students are not included in the study even if they are crucial to gain a valid data for the study.

Different data gathering tools such as; questionnaire, CBLM analysis and interview were used during the study. Data from the questionnaire is presented in a form of charts with a qualitative description below while the data gained from interview and document analysis were completely presented in a qualitative way.

\section{Context of the Study}

The study was conducted in the four government TVET colleges at East Gojjam Administrative Zone. Namely; they are Mertule Mariam ATVET College, Motta TVET College, Debrework ATVET Colleges and Bichena TVET College. They are located $365 \mathrm{~km}$, around $385 \mathrm{~km}$, around $275 \mathrm{~km}$ and around $250 \mathrm{~km}$ far from Addis Ababa respectively. The researcher selected the institution (TVET College) for that by thought no researcher can address the current problems in relation with language teaching in TVET as there are no responsible language teachers in TVET now. The colleges were also selected in view of the fact that its proximity to the researchers address and researcher good acquaintance with some of the teachers working in some of the colleges. There, as a result of which the researcher is encouraged to have a free and frequent communication with them.

\section{Sources of Data}

It would be fine if the data is going to be gathered from different concerned bodies and written resources. But, to make the study manageable and other constraints like time and budget, Data for the study is collected from four government TVET college ESP teachers, college academic vice deans and the course CBLM.

\section{Samples and Sampling Techniques TVET colleges}

There are 8 TVET colleges in East Gojjam Adiministrative Zone Amhara region. Even if it creates a sampling error, based on the researchers acquaintance with some of the teachers working in the college, the proximity of the college from the researchers adress only four (50\%) colleges were selected purposely . Therefore, MM ATVET College, Motta TVET College, Debrework ATVET College and Bichena TVET Colleges were the study area of the research.

\section{College Academic Vice Deans}

In each college there are one main dean and two vice deans. Those two vice deans are to manage the academic area and to manage the extension and technological areas. From those two deans from each college, only the academic vice deans from each college is selected purposefully because of their direct relation with the teaching learning process. As a result the number of sample deans was four.

\section{Instructors}

Based on the information gained from each college the total numbers of teachers who taught and is teaching work place communication at the time of this research are 54. As the number of ESP teachers in the selected ATVET College is few and can easily be managed, all the ESP teachers were selected in order to include a large sample size from the population. Availability sampling techniques was employed to select samples.

\section{CBLM}

The curriculum based learning materials were selected by using lottery system. Of all ESP course CBLM prepared by the course instructors, one CBLM were selected randomly from each college. Therefore, the total numbers of CBLMs selected for the study were three.

\section{Data Gathering Instruments}

The major instruments used in the study were CBLM analysis, Questionnaire, and interview. 


\section{CBLM analysis}

The activities (tasks) in the CBLM in all units (learning objectives) and contents of the course are examined to check the extent to which they are prepared based on the current theories of communicative tasks using Nunans (1989) frame work and Richards and Theodor, 2001 principles of communicative language teaching. According to MC Grath man (2002), check list is systematic, cost effective, provides a good deal of information to be recorded in a short period of time. It also helps to make an easy comparison between sets of materials.

\section{Questionnaire}

Questionnaire is one of the widely used research tools to elicit information about certain conditions and practices, especially to collect data on different phenomenons which are not easily observed such as attitudes and self concepts (Selinger and Sahomy, 1989).

Besides, it can be used to obtain background information about the research subject (Koul, 1984) so, the researcher used both close ended and open ended items. They were prepared for teachers to explore to what extent are the aforementioned factors affect teacher's implementation of CLT in ESP classrooms. The questionnaires were focused in five major categories that are background information of the respondents, student's related factor, teachers related factors, MOE especially TVET bureau related factors and institution related factors that affect the implementation of CLT in TVET ESP classrooms. The questionnaires were prepared for "Work place Communication Course teachers and they were prepared only in English language because it was thought that they can understand the overall messages of the questions since they are teachers.

\section{Interview}

The other technique that the researcher employed in gathering data was personal or individual interview. It was hoped to dig up appropriate information from the respondents. Roger (1997) clearly emphasizes the importance of interview as it is the most flexible means of obtaining information since face to face lends itself easily to questioning in greater depth and detail which is not possible through questionnaire and CBLM analysis.

The interview questions were prepared only for academic vice deans. It contained both structured and unstructured questions which were delivered orally or by reading the questions turn by turn as a subject responds (see Appendix-C). Unlike the questionnaire, the interview questions were presented in deans' vernacular language, Amharic to avoid the communication breakdown during the interview.

Before the interview, the researcher informed the participants about the purpose of the interview. The participants reviewed the questions briefly before the interview was conducted and then they were interviewed. It was deliberately done to maximize the reliability of the data obtained through questionnaire and document analysis.

The interview were videotaped with the approval of the participants, then transcribed and analyzed properly Participants were ensured that they had all the rights not to answer any questions that they feel uncomfortable. The interviewees response were carefully noted by the researcher for the purpose of interpretation and analysis of data ( see Appendix

\section{Data Collection Procedure}

The data collection process was arranged and carried out as per the college permission and an absolute willingness of the participants. No matter how, the procedure was; first ESP course CBLM from the selected colleges was examined, then the tasks (activities) in each unit of the CBLM were selected and were evaluated by using a checklist to see the extent to which these activities are well structured based on the principle of communicative tasks and to what extent they are matching with the work place communication course curriculum.

To collect the data from the deans the interview, first the researcher informed the participants about the purpose of the interview. The participants reviewed the questions briefly before the interview was conducted and then they were interviewed. It was deliberately done to maximize the reliability of the data obtained through questionnaire and document analysis.

The interview were videotaped with the approval of the participants, then transcribed and analyzed properly. Participants were ensured that they had all the rights not to answer any questions that they feel uncomfortable. The interviewees responses were carefully noted by the researcher for the purpose of interpretation and analysis of data (see Appendix E).

The data from the teachers' questionnaire were prepared and categorized in different categories to identify the factors that affect the implementation of CLT in ESP classroom. Then, the researcher give an orientation on the issues implied on the questioners what each questions were to meant before the teacher respondents started answering the questions and finally the researcher collected the question papers from each respondents. 


\section{Methods of Data Analysis}

Data gained through the questionnaire, document analysis and interview were analyzed in ----- parts based on the research questions. Analysis of the questionnaire involved interpreting data gained from participants of the study. The personal information of respondents was analyzed by reporting the number of people falling in different response categories. On the other hand, the majority of the questionnaire was analyzed through the themes and categories raised by the questions regarding the factors that affect the implementation of communicative language teaching that were MOE related factors, institutional related factors, teachers' related factors and students' related factors. Moreover, while the variables under the category of background information of the respondent were presented in a qualitative description, the variables under MOE related factors, institutional related factors, teachers related factors and students related factors were presented in a chart in a form of percentage using the existed number of sample population of the study followed by a brief qualitative description below.

Data from the document analysis Activities in the CBLM were examined using checklist which is prepared based on the principles of communicative activities. Then, they were analyzed qualitatively and thematically.the items in document analysis were categorized in to ----------- parts passed on the ------ major features of communicative tasks.

In analyzing the interview data, the raw data gained from the interview were recorded, then read and reread to have a complete understanding of the responses. It was simply analyzed by frequent listening to the video recording. Then, it was analyzed qualitatively. However, attempts were made to compare and contrast pieces of information gathered through different instruments during the data analysis.

\section{RESULT AND DISCUSSION}

The Purpose of this chapter is to analyze and discuss the data collected using the three research tools: questionnaires, document analysis and interviews in relation with factors affecting the implementation of CLT in ESP class rooms. In addition, the data gathered through all data gathering instruments have been treated using qualitative methods in words. For the purpose of discussion, the questions in the questionnaire are treated and classified into 5 categories as: personal information of the respondents, institutional related factors, teachers' related factors, TVET bureau related factors and students related factors. And so, the analysis starts with personal information and other details about the course instructors.

\section{Analysis of questionnaire data from college teacher respondents Back ground information of respondents}

Based on the data gained from the questionnaire among a total of 54 respondents, $36(66.7 \%)$ were male and18 (33.3) were female. Of them, only 7(13.0) teachers had a university degree and another $1(1.9 \%)$ teacher has a level III college diploma. The rest $46(85.2 \%)$ teachers had a level IV college diploma. Moreover, English was not the major field of study for all of the respondents. Regarding their services, all the teacher respondents had one to five years of service in teaching work place communication course. Therefore, most of the respondents in this group were males and had a level based diploma certificate. Moreover, English was not their major field of study. Regarding the average number of students in one class, there are a large number of students in Debre Work ATVET College ranging from 40 and above. This was because the college is newly opened college with no sufficient buildings. The rest Motta, Bichena and Mertule Mariam ATEVT colleges have an average number of students in between $25-30$ students in a class. (See appendix - F)

the adequacy of materials and conduciveness of TVET colleges for the implementation of CLT in their language teaching?

Teachers were asked to explain wether there are a conducive atmosphere and adequate materials to teach language in their colleges. To know this, TVET teachers were asked issues like; the number of students in their class, availability of wide classrooms to run communicative activities, allocation of time to offer the course,the teachers work load, and avaliabilitiy of authentic materials to teach language.

\section{Large Class Size}

It is one of basic element which plays a vital role in the implementation of CLT in ESP classrooms of TVET colleges. This part is the analysis of whether the class size is a problem to implement CLT in their college or not. From the questioner the researcher came to know that the number of students in the classes was not a major problem for Motta, Bichena, and Mretule Mariam ATVET colleges. According to the survey results the average number of students in their ESP classrooms is ranged from 25-30 students in all the above mentioned colleges. That is near to the standard. So, one can manage them easily during class room interaction.

One of the respondents explained that;

The standard of the average number of students in TVET classroom is 25. The average number of students in each of my classes is in between 25-30. Though it is above the standard, teachers can manage the overall 
activities of their trainees.

But, the respondents from Debre Work ATVET College replied large class size is their major problem to implement communicative Language Teaching. They stated that they have an average number of students ranged from 35 - 40 students in one class. The teachers confessed that large class size made it hard for them to use communicative language teaching in addition to other factors. Interestingly, one of the respondents of the questionnaire acknowledged the following information.

In my view, class size is related with the large number of students. The number of students in each of my class is 35-40. This is because the college is a newly opened college with no enough and standardized classrooms. So, the suffocation makes it difficult to manage the overall activities of the learners. Students could not move around and did not have time to practice the activities in class.

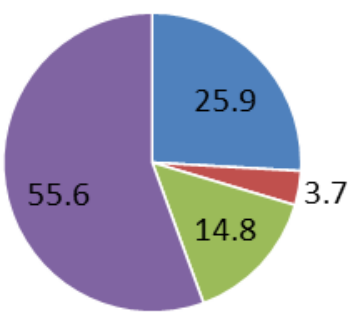

$$
\begin{aligned}
& \text { major problem } \\
& \text { managable problem } \\
& \text { minor problem } \\
& \text { not a problem }
\end{aligned}
$$

Fig 1: Large class size

\title{
Seating arrangement
}

This part presents the analysis of items related to sitting arrangement. Here teachers were asked if the classrooms are conducive to sit students in the way students' can run communicative activities. According to the questionnaire data $52(70.4 \%)$ of respondents all of them were from Motta, Debrework and Mertule Mariam ATVET colleges reported, sitting arrangement is not a major challenge facing them to implement communicative language teaching in their language class room. They explained that they teach their students in the workshops for which it is prepared to do their practical works for their major courses. They reported that the classes are wide and comfortable in which they can arrange in the way they like to run communicative activities even if they do not use communicative activities in their classroom teaching.

Since the sitting arrangement is highly depend on the size of the class, all the Debrework ATVET college teachers $(27.9 \%)$ of the total respondents pointed out it as a major problem, and another $1(1.99 \%)$ respondents mentioned that it is a minor problem. As it was mentioned in the large class size, the institution is new and have no enough and wide classrooms which comfort the teachers to run communicative activities.

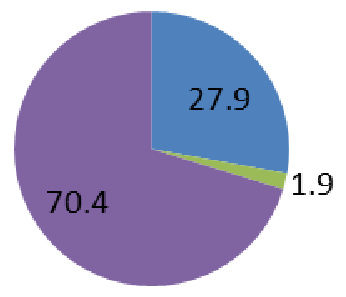

\author{
major problem \\ managable problem \\ minor problem \\ not a problem
}

Fig 2: seating arrangement

\section{Lack of time}

Time is one of the crucial element in the teaching learning process. The teachers were asked whether the allotted time to teach the "Workplace Commmunication Course" are adequate to finish the course and to equip the learners with the standard language or not. According to the questionnaire data it was surprised that only two respondent respond that lack of time is a manageable problem and not a problem respectively. They reported that they can elongate the allotted time to offer the course. This contradicts from the data gained from the text book evaluation, because the allotted time for the course was fixed and a gain it was allotted by MOE. So, no one can elongate the aforementioned time. The rest 52 (96.3\%) respondents thought the allotted time to finish the course (to equip the trainees with the needed standard) as a major challenge facing them in their language class room. The following excerpts from their response display how difficult situation this is for teachers.

In truly speaking, lack of time is the major factors affecting the practice of communicative activities in our ESP 
class room. The allotted time to finish the course is in between 25-30 hours. Within this time it is quite difficult to equip the learners with the standardized language needed by their employers. In addition, we teachers are busy with different responsibilities like participating in various meetings, committees so that we missed that little time reserved to give the course.

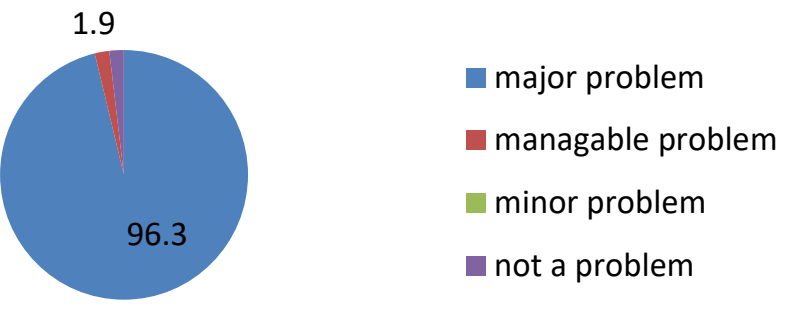

Fig3: lack of time

\section{Teachers heavy work load}

This part of the analysis is concerned with analyzing the work loads of teachers. Respondents were asked if they are loaded and if the load is a problem which prevented them from utilizing CLT in their work place communication classroom. It was reported as another serious barrier for teachers that prevented them from utilizing CLT in TVET. The data revealed that all respondents found this is a major challenge. The teachers were loaded with English language teaching program. All participants reported that they were supposed to cover too many tasks. First of all they were obliged to offer the course which they are not graduated in English. In addition, TVET left the preparation of language CBLM for the trainers without giving any language training as well as CBLM development. Teachers were also added they are busy with different responsibilities like participating in various meetings, committees in the college.

The same data was yield from deans interview. They reported that TEVT used a modularization system of teaching courses. As a result teachers in TVET are obliged to finish the course morning and afternoon with in the allotted time to finish the course. Therefore, it is possible to infer that the teachers feel exhausted when they teach in two shifts. I addition it is challenging to them to prepare a CBLM and teach the course with no specialization in the area.

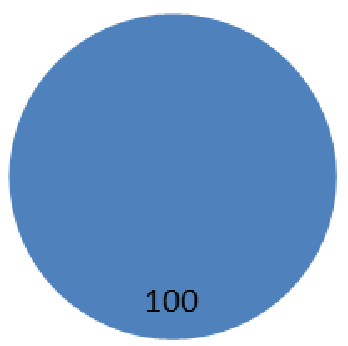

$$
\begin{aligned}
& \text { major problem } \\
& \text { managable problem } \\
& \text { minor problem } \\
& \text { not a problem }
\end{aligned}
$$

Fig 4: teachers heavy work load

\section{Lack of authentic material}

In this part of the analysis, what teachers think about the adequacy of materials to teach language is assessed. Teachers were asked to what extent the materials for language teaching are adequate in their college. It was surprise to see that $92.6 \%$ of respondents believed that lack of authentic material was not a challenge at all. They reported that, authentic materials are materials that the students can use in their field area not to teach language. So, it is possible to teach the trainees with some of the materials for their major course to improve their communicative competency that the trainees will use in their work context.

Lack of authentic material was also demonstrated by the deans interview result. Almost all the respondents of the interview reported that this was not a problem to implement communicative language teaching during classroom interaction. The interviewees revealed the above idea as follows,

The objective of teaching language for TVET students is to make the trainees know only the language in which they will face in their work area. To achieve this there is no doubt there should be an availability of authentic materials to teach language. And in my view authentic materials are materials which are not prepared for language teaching. Therefore, since the objective of learning language in TVET is to make the trainees 
communicate on work related issues, it is advisable to teach them using the actual materials prepared for the student's major courses. For example, one agriculture teacher can teach his/her students language effectively in the field site using the appropriate field materials practically rather than teaching them in a classroom using chalk and talk.

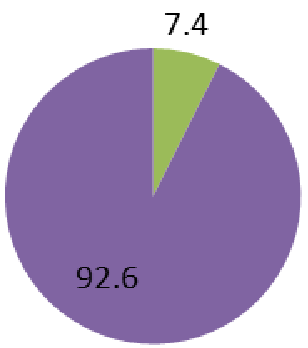

\author{
major problem \\ managable problem \\ minor problem \\ not a problem
}

Fig 5: lack of authentic material

\title{
Lack of supervision
}

It is well known that classroom supervision plays a vital role in indicating the effectiveness and drawbacks of the teaching learning process. Teachers were asked how often their deans supervise the work place communication class room. In response to this question, it was surprise that all the respondents from each college reported that any concerned body from TVET bureau, their department heads as well as their deans did not supervise the work place communication class room interaction. They reported that their attention was towards the student's major courses especially in agricultural and vocational areas. They reported that work place communication course is considered as a supportive course which is not that much important for their students.

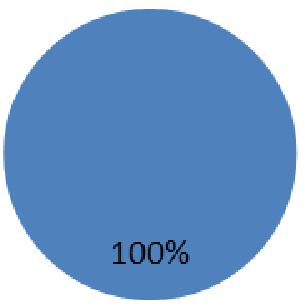

$$
\begin{aligned}
& \text { major problem } \\
& \text { managable problem } \\
& \text { minor problem } \\
& \text { not a problem }
\end{aligned}
$$

Fig 6: lack of supervision

\section{How ESP teachers influence the implementation of CLT in ESP classroom of TVET colleges?}

under this category both the ESP teachers and academic vice deans of the sample TVET colleges were asked issues on how the ESP teachers influence the implementation of CLT in ESP classes of TVET colleges. Teachers were asked issues like: how their speaking ability seems like, if they had a language teaching training, their attitude to wards English and English language teaching in general and their concept about CLT in particular, the parity of their major area of specialization and the "work place Communication Course", and their experiance in Language CBLM development.

\section{Deficiency in spoken English}

The questionnaire data showed that $75.90 \%$ of them reported their own deficiency in spoken English is a major challenge constraining them in applying CLT in their classroom. They justified that they are not English language professional teachers rather they are qualified in agriculture and vocational areas. They further stated that they have a deficiency in spoken English.

The data gained from deans' interview highly support it. The deans in the interview witnessed that most of the teachers in their colleges were TVET graduates. They reported that those teachers were exposed for English language teaching during their high school education and passed their college language education by being taught by non English professionals. Therefore, it is possible to suggest that most teachers have deficiency in spoken English.

On the other hand, $22.20 \%$ of respondent who had a university degree and learned English as a common course in their university education thought that deficiency in spoken English is a manageable problem. They explained that this time is a time of modernization so, any one can enhance his speaking skill using different technologies. 
Fig 7: deficiency in spoken English

Lack of training in CLT

The participants coincide in their response to the question regarding the opportunities they had training/retraining in CLT. $98.1 \%$ of the teachers thought it as a major challenge. They reported that no on job language training was given to teach the language rather they are obliged to teach the course which is new for them.

The deans participated in interview also explained it as it was a chronic problem that hinder the implementation of communicative language teaching in TVET ESP classrooms. They explained that teachers are assigned to teach the course regardless of their profession as well as with no language training on how to teach language. This shows that lack pre-service and in service training creates a major problem in the utilization of CLT in ESP classrooms.

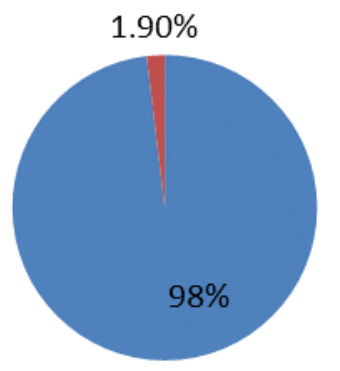

$$
\begin{aligned}
& \text { major problem } \\
& \text { managable problem } \\
& \text { minor problem } \\
& \text { not a problem }
\end{aligned}
$$

\subsubsection{Misconception about CLT}

\section{Fig 8: lack of training in CLT}

The majority of the teacher's confirmed that misconceptions about CLT were truly obstacle for them to make use of communicative activities in their class. While $1(1.9 \%)$ of the respondents believed that misleading notions about CLT served only as a manageable problem, the rest 53 (98 \%) teachers indicated that those misconceptions about CLT were serious barrier to implement CLT successfully in English classes. They noticed that their awareness in language in general and their awareness about communicative language teaching in particular was not that much satisfactory because of the reason that they are not qualified in teaching profession in general and in language teaching in particular.

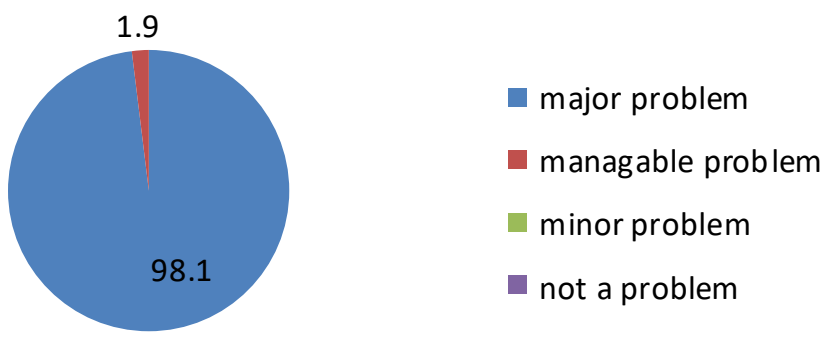

Fig 9: misconception about CLT

4.1.3.4. Mismatch between Teachers major area of Specialization and the Workplace Communication Course they offer

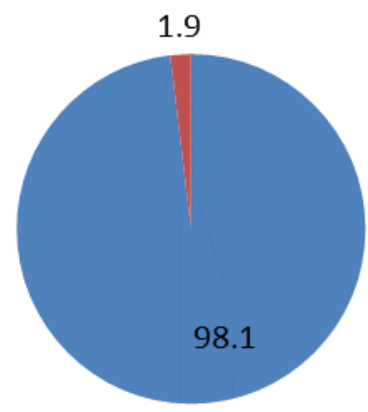

major problem

managable problem

minor problem

not a problem

Fig 10: Mismatch between teachers' major area of specialized and the work place communication course they offer 
The work place communication teachers were also asked if the mismatch between the course they graduate and the work place communication course is an obstacle to implement CLT in English class room. It was surprise that the entire teacher respondents pointed out there is a disparity between the course they specialize and the course that they were teaching at the time of this research study or had taught with in the previous past years. They realized that it is one of the most decisive factors that affect the implementation of CLT in their language teaching.

\title{
4.1.3.5. Lack of experience in CBLM development
}

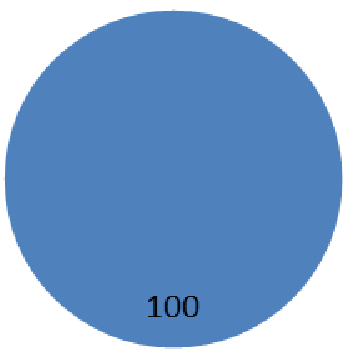

\author{
major problem \\ managable problem \\ minor problem \\ not a problem
}

Fig 11: lack of experience in CBLM development

As it is indicated in the above graph, all the teachers confirmed that their little experience in CBLM development creates a burden to implement CLT in their language teaching material. They explained that it is difficult to prepare a CBLM which prepare the trainees for a certain area of specialization and a CBLM which can achieve the over goals of the course curriculum without being professional in the area. Few of the respondents believed that their little experience in CBLM development served as a manageable problem. They stated that this time there are different online materials one can easily adapt/adopt it using internet.

\subsubsection{Attitude towards English and English language teaching}

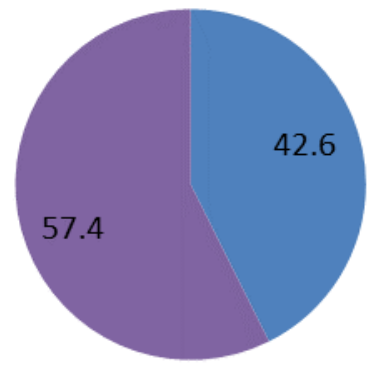

\author{
major problem \\ managable problem \\ minor problem \\ not a problem
}

Fig 12: attitude towards English and English teaching

Teachers also asked what their attitude towards English and English language teaching seems like. One of the good things gained from the teachers questionnaire is $57.4 \%$ teachers have a good attitude about English language as well as English teaching though they are not English language teachers. The rest 42.6\% respondents pointed out it as a major problem. They explained that it was because of their low English language that they could not promote their preparatory and university education. So, the researcher found teachers' attitude towards English language teaching is not that much a problem to implement communicative language teaching for most of the teachers while it is a major problem for others.

4.1.4. MOE Influence in the implementation of CLT in ESP classes of TVET colleges.

In this part the teachers and academic vice deans were asked: the availiability of language professional teachers, the suitability of the TVETs current language teaching policy, to what extent MOE particularly TVET bureau give an additional on job language teaching training for ESP teachers and to what extent TVET prepared ESP course CBLMs nationally and distribute it to all colleges.

\subsubsection{Shortage of Support (Giving additional on job training)}

In this question teachers were asked if they have had an in-service language teaching training. According to the questionnaire data, lack of support was one of the biggest challenges that the work place communication course teachers in TVET had to deal with in their attempts to incorporate CLT in to their teaching. All of them deemed lack of support as a major challenge. They reported that no on job language training is given to work place communication teachers. Regardless of their profession and giving training how to teach language they are assigned to teach the course. 
The same result is gained from deans interview. The deans were also explained no in service language training is given for their teachers. Their reason was the course is considered as a supportive course. In- service trainings were given to the teachers in their major area of specialization to feel the skill gap of the trainers.

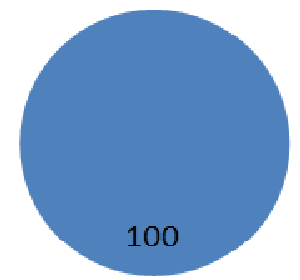

$$
\begin{aligned}
& \text { major problem } \\
& \text { managable prolem } \\
& \text { minor problem } \\
& \text { not a problem }
\end{aligned}
$$

Fig 13: shortage of support (giving additional on job training)

\subsubsection{Unable to Supply Nationally (centrally) Developed CBLM}

It was reported as another serious barrier for teachers that prevented them utilizing CLT in TVET ESP class rooms. The data revealed that all respondents found this as a major challenge. Even if it known that CBLMs were prepared in a way that it can have a positive effect on learners ' motivation, expose the learners to the real world language, support a more creative approach to teaching and provide authentic cultural information about the target language, TVET left CBLM preparation for the trainers who are not specialized in language by giving only the course curriculum.

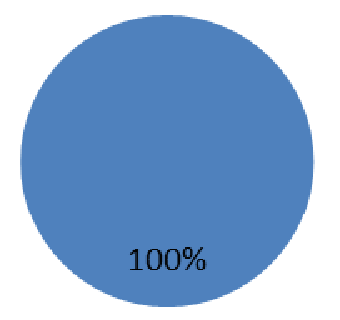

$$
\begin{aligned}
& \text { major problem } \\
& \text { managable problem } \\
& \text { minor problem } \\
& \text { not a problem }
\end{aligned}
$$

Fig 14: unable to supply nationwide developed CBLM

\subsubsection{Non availability of Professional English Language Teachers}

Teachers were asked if the absence of language professional teachers is a factor that affects the implementation of CLT in ESP class room. In response to this question the whole teachers replied that it was the most critical of all problems that affect the implementation of CLT in TVETs ESP class room.

Some of the respondents replied in a form of question. For example, one of the respondents said, "How someone who is a musician can teach language?" Another teacher respondent also said "can an English teacher teach physics? How it could be?" From this one may suggest that TVET seems forgotten the scince behind language teaching. So, this is one of the chronic factors that affect the implementation of communicative language teaching in ESP classrooms.

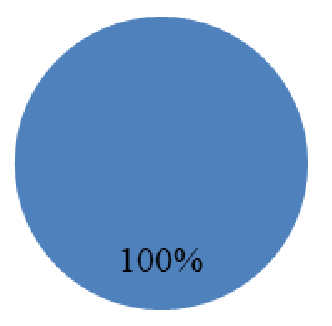

$$
\begin{aligned}
& \text { - major problem } \\
& \text { managable problem } \\
& \text { minor problem } \\
& \text { not a problem }
\end{aligned}
$$

\section{Fig 15: Non availability of English language professionals}

\subsubsection{TVET Current Language Teaching Policy}

As it is already implied on the figure $100 \%$ of the respondents confirmed that this was the most chronic factor of all other factors that affect the implementation of CLT in ESP classes. They reported that though CLT is implemented if the professional teachers offer the course, TVET made the course to be integrated with the major courses and to be given by non English professional teachers. They further reported that any employed teacher in TVET can teach the work place communication course regardless of their specialization. This implies that no 
attention is given to language teaching. The dean's interview also asserts this.

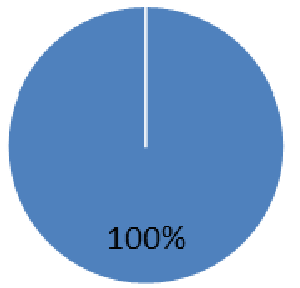

$$
\begin{aligned}
& \text { major problem } \\
& \text { managable problem } \\
& \text { minor problem } \\
& \text { not a problem }
\end{aligned}
$$

Fig 16: TVET current language teaching policy

\title{
4.1.5. Students influence in the implementation of CLT in ESP classes of TVET colleges
}

Here the teachers and academic vice deans were asked what their students English background and their motivation seems like in a "Work Place Communication Course" classroom.

\subsubsection{Low English proficiency}

$100 \%$ of the questionnaire respondents identified that low English proficiency as a characteristic problem of English teaching. They stated that students in TVET come with insufficient background in English because they are the students who are unable to join preparatory and higher institutions due to low academic achievement. In addition they explained that they are the trainees who come to gain a certain vocation or job.

The dean's interview report also shows that trainees in TVET are students who are unable to join higher institutions due to low academic proficiency or other exceptional individuals who want to be the owner of a certain vocation. Therefore it is possible to say that students' low English proficiency is one of the prominent factors which affect the implementation of CLT in a work place communication class room.

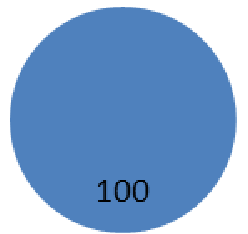

$$
\begin{aligned}
& \text { major problem } \\
& \text { managable problem } \\
& \text { minor problem } \\
& \text { not a problem }
\end{aligned}
$$

\section{Fig 17: low English proficiency}

\subsubsection{Passive style of learning}

The same thing is true in both the questionnaires response and deans interview. The whole respondents confirmed this as another serious problem. They replied that Students don't want to work and find information by themselves. They instead wait for what their teacher will provide. Even during class work, most of them want to copy what the cleaver classmates have done. Another reason that they explained why students are being passive during work place communication class room is student's expectation about the course. They said that the students expect the course as a common course which doesn't have value for them. As a result of this they are not eager to learn this course as they attend their major courses.

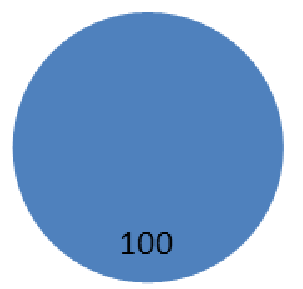

\author{
major problem \\ managable problem \\ minor problem \\ not a problem
}

Fig 18: passive style of learning

\subsubsection{Resistance to participate in communicative class activities}

They respond that due to low back ground in English most students use their mother tongue while doing communicative activities. They are waiting for what their teacher will provide. 


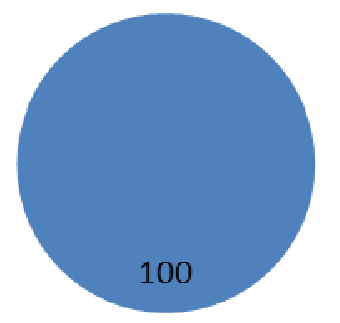

major problem

- managable problem

minor problem

not a problem

Fig 19: resistance to participate in communicative class activities

\subsection{Data from CBLM analysis}

In the study, the CBLM for level III horticulture crop production students from Mertule Mariam ATVET College, for level I Hotel Operation students from Motta ATVET College and for level I Automotive Engine and electrical Servicing students from Bichena ATVET College were analyzed. Particularly, the activities (tasks) in all CBLMs were analyzed in terms of their nature, based on Nunans ' (1989) communicative tasks criteria.

\subsubsection{Occurrence of Communicative Activities}

As one can see in the appendix $G$, there are no communicative activities in each of learning outcomes of each CBLM from different colleges. There is no any communicative activity that requires learners' interaction. The activities in the CBLM includes; true false items, matching, multiple choice items and give short answer questions. Therefore it is possible to infer that the activities in the CBLM is prepared by non English professionals This implies that the activities presented in the CBLM may not get enough opportunity to practice CLT and to equip the trainees with the needed standard language and to achieve the objectives of the course curriculum. Moreover, the non communicative activities in the CBLM are placed at the end of each learning outcome (units). This implies that learners may not have the opportunity to practice during class room interaction. They have the opportunity to learn only the theoretical aspects offered by the teacher.

\subsubsection{Evaluation of the Communicative Activities in the CBLM}

\subsubsection{Having a purpose that goes beyond the classroom exercise}

The activities in the CBLM were assessed and analyzed to see to what extent the tasks in the CBLM have the purpose beyond the class room exercise.

Regarding this Harmar, 1991 stated, if a task is to be genuinely communicative and promote language use, they should make students communicative in the target language. Besides tasks should have a purpose for using language, and this purpose is the most important part of communication. Therefore students' attention should be created in context i.e on what is being said or written but not, on the language form that is being used.

In all the learning outcomes of the CBLM, (see appendix G) learners are asked to answer true false items, multiple choice items, matching items and give short answer items which are far from communicative ways of language testing and assessment. The activity does not allow the students to do the activities that they will practice in their work area. Therefore, it is possible to suggest that activities in the CBLM do not have an outside world reflection for which the students are trained for.

\subsubsection{Inclusion of communicative activities}

The activities in the CBLM were assessed and analyzed to see to what extent communicative activities like; jigsaw activities, problem solving activities, decision making activities, opinion exchange tasks dramas, role plays, meeting, storytelling, and puzzles are included in the CBLM. It was surprise that no communicative activities which are mentioned above are existed in the CBLM. This implies that, the activities in the CBLM were not prepared in line with the objective of the course by non English professionals. Data gathered through questionnaire and interviews highly support this. The data gathered through questionnaire and interview indicated that ESP teachers in TVET are not English language professional teachers as the same time they have no any experience in CBLM development for language courses.(see appendix G)

\subsubsection{Real world reflection}

The activities in the CBLM were assessed and analyzed to see to what extent that communicative activities have a real world reflection. In other words they are analyzed to see to what extent the activities in the CBLM have the students' real work place communication reflection. Though TVET is a remarkable place to prepare an ESP course CBLM which contains well organized communicative activities based on the language needs of the trainees, the activities in the CBLM does not have any right work place communication reflection. The activities in the CBLM makes the students learn and use English almost solely at school at the end of the unit. (See appendix G) 


\subsubsection{Promote learning by doing}

The activities in the CBLM were assessed and analyzed to see to what extent activities in the CBLM promotes learning by doing. TVET seems forgotten that English is a practical course as like as agriculture and vocation courses. The activities in the CBLM were not prepared in which the students can learn English by doing communicative activities. The activities were prepared in which the students can do individually by pick the answer. (See appendix G)

\subsubsection{Effectiveness to achieve the stated objectives of the course curriculum}

Even though the work place course curriculum objectives in each CBLM were stated in the curriculum in the way that the teachers could understand, no activity asked the students to show when they communicate information, lead work place discussion, identify issues and communicate on issues arising in the work place. For example the following can be taken as an example to show that the objectives are clear enough and they are also motivating and encouraging students to apply the class room practice in to the real world.

E.g. At the end of this module the trainees will be able to:

Lo1: communicate information about work place process

Lo2: lead work place discussion

LO3: identify and communicate issues arising in the work place (see appendix $\mathrm{H}$ )

\subsubsection{Input}

It is another important communicative component that the text book writers and syllabus designers need to take in to consideration. Input also is a term used to mean the language that students hear or read. The input in the text book needs to be clear and authentic as much as possible, so as to make the students interested and motivated. Authentic input exposed students to a real life situation. Therefore, the CBLM should consist meanses of presenting inputs like (dialogue, discussion topic, pictures, storytelling activities. as it can be seen in the appendix, there are no meanses of presenting inputs in all CBLM activities. (See appendix G)

\subsection{Data from Academic vice Deans` Interview}

As one can see in appendix $\mathrm{C}$ and $\mathrm{E}$ First of all, all the deans were asked how long they have been a college dean In response to this question Dean the deans have an average 4 years of experience in a position of academic dean.

The second question asked the deans if there is any problem regarding to the teaching of English language (work place communication) course in their college. As to this question, all of the deans replied that there was a resistance to offer the course by the teachers. They reported that teachers were not interested to offer the course. Teachers raised a question the course does not belong to us. The right language professional should offer the course. If not, TVET have to give us training on how to teach language.

During the interview the deans were asked if there is an adequacy of materials ( wide classes, chairs, tables , CBLM and other materials that students can use in their field area to teach the course ' work place communication'? as a response to this question all the deans reported that there are adequate materials in our work shop to teach language. They further explained that the aim of language teaching for TVET students is to make the students communicate on their workplace issues. Therefore, communication on work place issues can be teaching effectively using the practical materials that the students will use in their work area. Those materials are saturated in our work shop. This might go with the result obtained from teacher's questionnaires.

The academic vice deans were also asked if their work place communication teachers have taken any language training? In response to this question all the deans reported that their work place communication course teachers had taken English as a course during their high school education. They further reported that they are simply assigned to teach the course even if they are not language graduate student. As it is already discussed in the questionnaires transcription the same data is yield from teacher's questionnaire.

Question 2 asked the deans how often they supervise the work place communication teachers in their English class room. It was surprise that all the deans were not supervised their work place communication class room interaction. They reported that their attention was towards the student's major courses especially in vocational areas. They reported that work place communication course is considered as a supportive course which is not that much important for their students.

The interview question was also asked the deans to point out the major factors that hinder the teaching of ' work place communication course in a communicative language teaching approach? Regarding to this question all the deans were asked to answer the question by looking it from four perspectives that are institutional factors, TVET beaurue related factors, teach related factors and students related factors.

Regarding to this question all the deans tried to list the most chronic problems from the above mentioned four elements. The majority of the deans agreed that lack of time, heavy work load, lack of supervision were the most decisive institutional factors. Being not professional in language (the mismatch between the major area of study and the work place communication course they offer), low English knowledge, giving little attention for the course are also the basic teachers related factors that affect the implementation of CLT in a work place communication class room. 
The deans also reported that, Exclusion of language teachers from TVET system, unable to supply nationally developed content based learning material for work place communication, limitation in giving additional on job language training rather than simply assigned teachers to teach a course for whom they are new were the most influential Ministry of education related factors of all factors that affect the implementation of CLT in ESP class room.

Moreover, they explained that low English proficiency of students, passive style of learning and resistance to participate in communicative activities were also another additional problems which encounter an ESP teachers of TVET class room. They said that students were not observed when they focus on supportive courses not only English the same is true in civic, and entrepreneur courses

\section{Summary}

As noted earlier in the introductory section of this research work, the purpose of the study was to investigate factors that affect the implementation of CLT in the ESP classes of East Gojjam Zone ATVET colleges. In addition the study has been designed to specifically address the three basic questions outlined in chapter one. In order to reach at the overall purposes of the study and deal with the three basic questions, therefore, three types of data gathering instruments i.e questionnaire, interview and text book analysis were used. After completing an interaction with the participant teachers and College deans, the data were gathered through the aforementioned instruments and organized, categorized and discussed qualitatively in chapter four. The data were obtained from purposely selected work place communication teachers, college academic vice deans and the course CBLM. In order to create a holistic picture of qualitative data, the researcher integrated and discussed all the data jointly under key successive topics of the study.

The findings of the study discovered that ESP teachers in East Gojjam zone ATVET Colleges confront with several challenges in implementing communicative Language Teaching. It was found that most of the participant teachers and academic vice deans focus on the trainee's major field of study so as to make them competent in vocational skills. The findings of the study again indicated that the essential elements of CLT were not practiced in the ESP class rooms of ATEVT colleges due to various challenges of the MOE, the institution (college), the teachers and the students.

They emphasized absence of language teachers from TVET system, unable to prepare a CBLM nationally, shortage of giving on job language teaching training, TVET current language teaching policy from MOE related factors; lack of time , heavy work load, lack of supervision from institutional related factors; deficiency in spoken English, lack of training in CLT, misconception about CLT, lack of experience in CBLM development from teachers related factors and low English proficiency, passive style of learning and resistance to participate in communicative activities from student related factors were the major factors that challenge teachers in implementing CLT approach in ESP class room.

Moreover, the study discovered that the work place communication CBLM activities were not prepared based on the common features of communicative activities. It was also discovered that MOE especially TVET bearue, ESP teachers, school deans, students, different industrial sectors who needs TVET graduates were the most responsible bodies to alleviate the challenges and improve the implementation of communicative language teaching in East Gojjam Zone ATVET Colleges.

\section{Conclusions}

From data presentation and discussion, the following conclusions have been made.

1. The non availability of language teachers in TVET colleges is the most influential factor that affects the practice of CLT in ESP class room. TVET made the course to be offered by an individual which is not qualified in language area. Where ever there is no right man at the right place, there will be considerable challenge in the practice of communicative language teaching.

2. Nationally developed course CBLMs were not available in TVET colleges. TVET left CBLM development for agricultural and vocational teachers to prepare a CBLM for English course (work place communication) without giving any training on how to prepare a language teaching material. It is possible to suggest that work place communication CBLMs were not prepared as per the objectives of the course curriculum and students cannot gain the same knowledge as the module preparation may vary based on the course instructors wisdom.

3. Less emphasis is given to English language teaching by TVET. They considered language teaching as a simple task that anyone can teach without any difficulty. No on job English language training is given to work place communication. ESP teachers are simply assigned regardless of their field of study.

4. There is no any clearly designed language teaching policy in TVET. TVET wants to give the English course by integrating it with the agricultural and vocational fields by agriculture and vocation course teachers. In other words any employed teacher in TVET can teach an English course (work place communication).This clearly indicated that the current language teaching policy is not properly 
designed to achieve the objectives of the course curriculum.

5. Though TVET used a modularization system of education which is much more conducive to implement CLT without any interference of any other subject, the allotted time to equip the trainees with the needed standard language is not enough.

6. The assignation of agriculture and vocational field teachers as a language teacher and the desire to make the work place communication teachers to prepare a CBLM without being professional in the area were a clear depiction of teachers work load to implement CLT.

7. Since the focus of TEVT colleges is towards the trainee major course areas that makes them get a job no attention is given for language teaching. No supervision is conducted via English language teaching in TVET.

8. As most of the teachers who teach the course work place communication are TVET graduates, they do not have the opportunity to learn language after they complete grade 10. As a result, most of the teachers have a deficiency in spoken English.

9. All the teachers who give the course work place communication are agriculture and vocational department teachers. Due to that, teachers have no awareness about language teaching in general and communicative language teaching in particular.

10. No language teaching training as well as language course CBLM development training is given to the work place communication course teachers. This makes teachers over loaded to teach English.

11. Students in TVET are the one who are unable to join preparatory and higher institutions due to low academic achievement. Due to that, Students don't want to work and find information by themselves. They instead wait for what their teacher will provide. Even during class work, most of them want to copy what the cleaver classmates have done. Not only that they are also being passive during work place communication class room. They expect the course as a common course which doesn't have value for them. As a result of this they are not eager to learn this course as they attend their major courses. Moreover, students were resisted when they are invited to participate in communicative class activities. They use their mother tongue while doing communicative activities otherwise; they are waiting for what their teacher will provide.

12. Tasks in the CBLM do not include communicative activities; like role play, drama, picture, problem solving activities, meetings which are much more influential to act out the language that they will use in their work area.

\subsection{Recommendations}

Based on the findings of the study, the following recommendations are of real importance.

1. MOE should revise the current language teaching policy of TVET for the better implementation of CLT in ESP class rooms by holding an appropriate supervision in ESP class rooms.

2. The professional teachers should be assigned to offer the course work place communication. Otherwise; massive CLT training should be provided for ATVET college English teachers.

3. Syllabus developers should conceder the basic elements of CLT in each learning outcome or unit

4. Syllabus designers should allocate adequate time for the course in order to equip students with the standard language.

5. The curriculum as well as the CBLM for the course work place communication course should be prepared by the language experts.

6. Language COC assessment should be given to the trainees so as to arise students motivation in a work place communication class room.

7. As like as agricultural and vocational courses, due attention should be given to the work place communication course. Appropriate supervision should be held in a work place communication course class room.

8. A work place communication course CBLM should be developed nationally so as to give a nationwide knowledge for all trainees throughout the TVET colleges.

\section{References}

Alemayehu H/mariam ,2012. "school factors affecting teachers implementation of communication Language Teaching."(un published M.A thesis) Haramaya : Haramaya University

Bill - Gill ham. 2000. Case study research method ( $1^{\text {st }}$ ed)

Creswell,J,W. 2003. Research design: quantitative, qualitative and mixed approaches ( $2^{\text {nd }}$ ed.)

Dudley - Evans and st,John . 1998. Developments in English for specific purpose. Cambridge: Cambridge University Press

Finch and Crunkilton,1999. Curriculum development model in Vocational and Technical Education: planning, content and implementation $5^{\text {th }}$ edition. 
Gashaw Shewangizaw .2007. "English language need analysis of $10+3$ tank Mechanics trainees of major General Mulugeta Buli Technical and Vocational Education Training College"(un published )M.A thesis ,Adiss Ababa : Adiss Ababa University

Hedge, T.(2000) Teaching and learning in the Language classroom. Oxford : Oxford University Press.

Hutchinson ,T and waters .1987. English for specific purpose. Cambridge: Cambridge University press

Hutchinson,T and Waters,A.1994. English for Specific purpose.Cambridge: Cambridge University press.

ICDR, 1994. Education Training Program Including Period Allotment and Content Selection Criteria: Short Term Plan for Developing and implementing the new Curriculum. Unpublished, Adiss Ababa, Ethiopia.

ILO,2010. Teachers and Trainers for future TVET in changing the world. Geneva: ILO.(2012). Implementing Competency - based Training (CBT) in Bangladish. Bangladish

Keiser, J,Lawrenze,F., and Appleton,J.,(2004). Technical Education Curriculum Assesment . journal of Vocational Education research 29(3) 181 - 194). Minnesota: Dunwoody college of technology and university of Minnesota.

Koul.L.1984. Methodology of Educational Research.New Delhi: Vikas publishing Ltd

Kreeft.P.J (1997). Professional development for forign language teachers, ERIC digest,Washington DC: ERIC cleaning house on language and lingustics

Lakachew Mulat.2003. "Teachers Attitude towards CLT and practical problems in its Implementation.”(unpublished)M.A Thesis,Adiss Ababa:Adiss Ababa University

Larson -freeman,D.1986. Techniques and principles in language teaching oxford: oxford University press

LittleWood,W.1981. Communicative Language Teaching Cambridge: Cambridge university press.

MOE.2007, Ethiopia TVET-system,Guideline (recommendation Curriculum Development.Adiss Ababa:MOE

Mohhamed Sied.2007. " discovering the English language needs of learners (cadgets) the case of Ethiopian police college." (unpublished )M.A thesis, Adiss Ababa: Adiss Ababa University

Munby ,J, 1987. Communicative Syllabus Design Cambridge : Cambridge University Press.

Nunan .1989. Designing Tasks for the Communicative class room, Cambridge: Cambridge University Press

Nunan ,D.1991. Communicative Tasks and the Language Curriculum. TESOL Quarterly 25/2,279 - 296

Richards, J. 2001. Curriculum development in language Teaching. Cambridge: Cambridge University Press

Richards, J.C .2006. Communicative language teaching to day

Richards, J. and Rodgers,T .2001. Approaches and methods in Language Teaching New York: Cambridge University Press

Robinson, p. 1991.ESP today: A practitioner`s Guide United King Dom Prentice hall international

Savigon,s .1991. "Communicative Language Teaching: State of the Art." In TESOL quarterly. vol.25; 2: 261276.

Selinger, H, W, and E Shohamy .1989. Second Language Research Methods Oxford: Oxford University press

Sharma, A.2008. Technical Vocational Education and Training (TVET) in Africa. Adiss Ababa :AU

Surafel Zewdie, 2002. The effects of the new English Language Teaching Methodology in the First Cycle Secondary Schools. Educational journal 6/13:70 - 86

Tagel Elias .2007. " An investigation in to the English Language course Needs Electricity students of Dilla TVET collge." ( unpublished) M.A. thesis, Adiss Ababa: Adiss Ababa University

Tashakkori,A, and Teddle,C.1998. Mixed methodology:combining qualitative and quantitative approaches. Thousands oaks.CA:sage

Widdowson ,H.G. 1983. Learning purpose and Language use. Oxford

Wilkins, D., 1976. Notional Syllabuses.Oxford University Press

Wright ,T., 2000. Communicative Language Teaching . can it work for us?In EELTNET. Adiss Ababa : British Council 